\title{
Socio-Economic Determinants of Household Income among Ethnic Minorities in the North-West Mountains, Vietnam
}

\section{Tran Quang Tuyen}

Faculty of Political Economy, VNU University of Economics and Business, Hanoi, Vietnam

tuyentq@vnu.edu.vn

\author{
CroEconSur \\ Vol. 17 \\ No. 1 \\ June 2015 \\ pp. 139-159
}

Received: January 9, 2015

Accepted: June 16, 2015

Research Article

doi:10.15179/ces.17.1.5

\section{Abstract}

This paper investigates both commune and household determinants of household income among ethnic minorities in the North-West Mountains the poorest region of Vietnam. The findings show that the vast majority of the sample households heavily depend on agricultural activities. Factors affecting household income per capita are examined using multiple regression models and the findings confirm the important role of education, non-farm employment and fixed assets in improving household income. In addition, some commune variables such as the presence of the means of transportation, post offices and non-farm job opportunities are found to have an increasing impact on household income. The findings suggest that policies for poverty reduction should aim at both commune and household levels. Policies that focus on improving the access 
of ethnic minorities to education and non-farm employment are expected to be effective ways of enhancing their income.

Keywords: ethnic minorities, non-farm participation, household income, North-West Mountains

JEL classification: $\mathrm{I} 32, \mathrm{O} 12, \mathrm{~J} 15$

\section{Introduction}

Vietnam has 54 ethnic groups, of whom the Kinh (Viet) are by far the biggest group, accounting for nearly 74 million people (85.7 percent of the total population) (World Bank, 2012). There are five other ethnic groups (the Tay, Thai, Muong, Khmer and H'mong) having populations of more than 1 million, and another three (the Nung, Dao and Hoa) with populations between 500,000 and 1 million. There are also a number of ethnic groups whose populations are less than 5,000 people. With the exception of the Hoa (Chinese), Khmer and Cham, other ethnic minority groups mainly reside in highland or upland areas, away from the coastal plains and major cities. The largest minority populations live in the North-West, North-East and the Central Highland regions, although there are also ethnic minority groups in the North-Central, South-Central and Mekong regions (World Bank, 2012).

Vietnam has recorded great achievements in economic growth and poverty reduction over the past two decades. The share of population living below the poverty line reduced significantly from 58 percent in 1993 to 20 percent in 2004 and 15 percent in 2010 (Cuong, 2012). Despite prominent progress in alleviating overall poverty, including a steady reduction in ethnic minority poverty, there remains a large and increasing gap in living standards and poverty rates between the Kinh majority and ethnic minorities. The proportion of minorities among the poor increased from 29 percent in 1998 to 47 percent in 2010. There was still about 66 percent of ethnic minorities living below the poverty line and around 
37 percent living below the extreme poverty line in 2010. By contrast, the figures for the Kinh majority population were only about 13 percent and 3 percent, respectively (World Bank, 2012). In particular, there is a substantial proportion of ethnic minorities living in the North-West Mountains with a very low income and limited access to infrastructure, education, health services and non-farm employment (Cuong, 2012). About 73 percent of the ethnic minorities in this region were still poor and 45.5 percent were extremely poor in 2010 (World Bank, 2012).

Possibly due to the widening gap in living standards between the ethnic minority and majority groups in Vietnam, an increasing number of studies have examined the disparity in income or expenditure consumption between the two groups (e.g., Baulch et al., 2007; Baulch et al., 2011; Cuong, 2012; Minot, 2000; Van de Walle and Gunewardena, 2001). However, to the best of my knowledge, very few studies have investigated factors affecting household income among the ethnic minorities in Vietnam and, furthermore, no study examines the determinants of household income among the ethnic minorities in the NorthWest Mountains. A better understanding of factors affecting household income of the ethnic minorities in this poorest region is of much importance, especially when designing policy interventions to improve their welfare. Hence, the current study was conducted to fill in this gap in the literature.

The main objective of this study is to examine the socio-economic determinants of household income among ethnic minority households in the North-West Mountains, Vietnam. This is the first study to analyze both commune and household factors affecting household income by using a unique dataset from a recent Northern Mountain Baseline Survey. Therefore, the study adds to the existing literature by providing the first econometric evidence for factors affecting household income of the ethnic minorities in the poorest region of Vietnam.

The paper is structured into five sections. The next section presents a brief literature review on determinants of household income. The third section 
describes the data source and econometric models used in this study. The fourth section presents the determinants of household income, while the conclusion and policy implications are presented in the final section.

\section{Literature Review}

According to Benin and Randriamamonjy (2008), the literature on the determinants of household income is well established, dating back from the literature on human capital development, economic growth and poverty alleviation (e.g., Schultz, 1961; Welch, 1970) to more recent studies using household data (Hassan and Babu, 1991; Lanjouw and Ravallion, 1995; Simler et al., 2004; Otsuka and Yamano, 2006). The main factors affecting household income include household size, the age and gender of household members, composition of the household, education, health, social capital, assets and endowments, and employment, among others. There are also community factors that significantly determine household income such as weather, prices and infrastructure (Benin and Randriamamonjy, 2008).

Empirical evidence shows that the size and composition of households are closely associated with household income. Household size and dependency ratio are found to reduce household income per capita (Tuyen et al., 2014; Jansen et al., 2006). Among other factors, education of household members is often found to have a positive effect on rural household income (Estudillo, Sawada and Otsuka, 2008; Jolliffe, 1997; Nguyen, Kant and MacLaren, 2004; Yúnez-Naude and Taylor, 2001). However, the income effect of the age of household members might be ambiguous. Households with younger working members are more likely to undertake non-farm jobs, which in turn might earn higher incomes. Nevertheless, households with older working members tend to attain more work experience, which might enable the households to earn higher income (Tuyen, 2014a).

Ethnicity is also found to be a key determinant of household income and poverty. Ethnic minority households are much poorer than ethnic majority households 
in most countries (Barnard and Turner, 2011). Empirical evidence indicates that ethnic minority groups are much poorer than the Han majority in China, and ethnic minorities are also much poorer than the Hindu majority in India (Bhalla and Luo, 2012). Similar findings have also been found in developed countries. For instance, a study by Weiss (1970) in the United States revealed that on average, African Americans had lower income than white Americans with the same number of years of schooling. In England, about two-fifths of ethnic minorities live in income poverty, twice the rate for the white population (Kenway and Palmer, 2007). One of the main reasons that can explain the low income and high poverty among ethnic minorities is social exclusion. As noted by Thorat and Newman (2007), ethnic minorities are more likely to be economically and politically marginalized and excluded from society. Exclusion can take several forms such as economic, social, political and legal forms. Ethnic minorities might suffer from both market and non-market discrimination.

Some other household characteristics, namely productive assets, access to credit and land are also positively linked with household income. Access of rural households to both formal and informal credit has improved their living standards in some developing countries (Cuong, 2008). In particular, empirical evidence confirms that land has a positive effect on household income in several developing countries (Carletto et al., 2007). Other evidence shows that employment status, especially non-farm employment, plays an increasingly important role in rural household income (Rigg, 2006; Tuyen, 2014b). Empirical studies indicate that non-farm participation has a positive association with household income in China (Micevska and Rahut, 2008), Honduras (Ruben and Van den Berg, 2001), Ghana (Ackah, 2013), Mexico (Yúnez-Naude and Taylor, 2001) and Vietnam (Pham, Bui and Dao, 2010).

Some community characteristics are also found to have a significant effect on rural household income. For instance, basic infrastructure such as the availability of rural roads has a positive effect on household income in Nigeria (Kassali et al., 2012). Access to rural electricity is found to increase income for rural households 
in Vietnam and Bolivia (Gauri, 2001; Khandker et al., 2009). In addition, Gauri (2001) found that access to markets and major roads has an increasing impact on household income in Bolivia. Also, access to local irrigation is found to have a positive effect on household income in Nigeria (Tijani et al., 2014). Finally, the geographic location is also a key determinant of household income in several developing countries. For example, households living in mountainous areas are more likely to be poor in Vietnam (Van de Walle and Gunewardena, 2001) and China (Gustafsson and Sai, 2008).

\section{Data and Methods}

\subsection{Data Source}

The commune and household data from the 2010 Northern Mountains Baseline Survey (NMBS) were utilized for the current study. The 2010 NMBS was conducted by the General Statistical Office of Vietnam (GSO) from July to September in 2010 to collect baseline data for the Second Northern Mountains Poverty Reduction Project. The main task of this project is to focus on reducing poverty in the Northern Mountains region, Vietnam. The project has invested in productive infrastructure and provided support for the poor. The project has been implemented in six provinces in the North-West region, including Hoa Binh, Lai Chau, Lao Cai, Son La, Dien Bien and Yen Bai (Cuong, 2012).

A multi-stage sampling technique was employed for the survey. Firstly, 120 communes from the six aforementioned provinces were randomly chosen following probability proportional to the population size of the provinces. Secondly, from each of these selected communes, three villages were randomly selected and then five households in each village were randomly chosen for the interview, yielding a total sample size of 1,800 households. The survey covered a large number of households from various ethnicities such as Tay, Thai, Muong, H'mong and Dao. 
Both household and commune data were gathered for the survey. The household data consist of characteristics of family members, education and employment, healthcare, income, housing, land, access to credit, fixed assets and durables. The commune data contain information about the characteristics of the communities such as demography, population, infrastructure and non-farm job opportunities. The commune data were merged with the household data for the research purpose of this study.

\subsection{Data Analysis}

The main statistical analyses applied in this study were descriptive statistics and regression analyses. First, households were grouped into poor and non-poor households using the poverty line for rural households (400 thousand VND ${ }^{1}$ / person/month). Once households were divided into poor and non-poor groups, statistical analyses were applied to compare the means of household characteristics and assets between the two groups. Analysis of variance (ANOVA) models were used to do so. In addition, a chi-square test was utilized to analyze whether a statistically significant link existed between two categorical variables such as the type of household (poor or non-poor household) and the type of employment.

Because the dependent variable (household income per capita) is a continuous variable, econometric models using ordinary least squares were used in the study. The regression models were used to analyze relationships between per capita household income and various explanatory variables, including household and commune-related variables. Specifically, several explanatory variables were selected as being important to household income (Table 1). These were (i) household size, dependency ratio, gender, age and education of household head; (ii) owned farmland size per capita, the log of total values of all fixed assets, total value of loans; (iii) participation in non-farm activities; (iv) the presence of means of transportation, paved roads, post offices, electricity, local markets, irrigational work and non-farm job opportunities and population density. 
Table 1: Definition and Measurement of Explanatory Variables Included in the Models

\begin{tabular}{|c|c|c|}
\hline $\begin{array}{l}\text { Explanatory } \\
\text { variables }\end{array}$ & Definition and measurement & $\begin{array}{l}\text { Expected } \\
\text { sign }\end{array}$ \\
\hline Household size & Total household members (persons) & - \\
\hline Dependency ratio ${ }^{b}$ & Proportion of dependents in the households & - \\
\hline Age & Age of household head (years) & $+1-$ \\
\hline Age squared & The squared age of household head (year) ${ }^{2}$ & $+1-$ \\
\hline Gender $^{\mathrm{a}}$ & Whether or not the household head is male $($ male $=1$; female $=0)$ & $+1-$ \\
\hline Primary education ${ }^{a}$ & Whether or not the household head completed primary school & + \\
\hline $\begin{array}{l}\text { Lower secondary } \\
\text { education }\end{array}$ & $\begin{array}{l}\text { Whether or not the household head completed lower secondary } \\
\text { school }\end{array}$ & + \\
\hline $\begin{array}{l}\text { Upper secondary } \\
\text { education and higher }\end{array}$ & $\begin{array}{l}\text { Whether or not the household head completed upper secondary } \\
\text { school or higher level }\end{array}$ & + \\
\hline Annual crop land & The size of annual crop land per capita ( $100 \mathrm{~m}^{2}$ per person) & + \\
\hline Perennial crop land & The size of perennial crop land per capita $\left(100 \mathrm{~m}^{2}\right.$ per person $)$ & + \\
\hline Forestry land & The size of forestry land per capita $\left(100 \mathrm{~m}^{2}\right.$ per person $)$ & + \\
\hline $\begin{array}{l}\text { Water surface for } \\
\text { aquaculture }\end{array}$ & $\begin{array}{l}\text { The size of water surface for aquaculture per capita }\left(100 \mathrm{~m}^{2} \text { per }\right. \\
\text { person) }\end{array}$ & + \\
\hline Fixed assets & $\begin{array}{l}\text { Total value of all fixed assets per capita (log of one thousand } \\
\text { VND) }\end{array}$ & + \\
\hline Credit & $\begin{array}{l}\text { Total value of loans that the household borrowed during the last } \\
24 \text { months before the time of the survey (one million VND) }\end{array}$ & + \\
\hline Wage employment ${ }^{\mathrm{a}}$ & Whether or not the household engaged in paid jobs & + \\
\hline $\begin{array}{l}\text { Non-farm self- } \\
\text { employment }^{\mathrm{a}}\end{array}$ & $\begin{array}{l}\text { Whether or not the household took up non-farm self- } \\
\text { employment }\end{array}$ & + \\
\hline Paved road ${ }^{\mathrm{a}}$ & $\begin{array}{l}\text { Whether or not there is any paved road to the commune in } \\
\text { which the household lived }\end{array}$ & + \\
\hline Electricity $^{\mathrm{a}}$ & $\begin{array}{l}\text { Whether or not electricity is available in the commune in which } \\
\text { the household lived }\end{array}$ & + \\
\hline Local market $^{\mathrm{a}}$ & $\begin{array}{l}\text { Whether or not there is any market in the commune in which } \\
\text { the household lived }\end{array}$ & + \\
\hline $\begin{array}{l}\text { Means of } \\
\text { transportation }^{\mathrm{a}}\end{array}$ & $\begin{array}{l}\text { Whether or not means of transportation such as minibuses, } \\
\text { passenger cars, vans, three-wheel taxis or motorbike taxis are } \\
\text { available in the commune in which the household lived }\end{array}$ & + \\
\hline Irrigational work $^{\mathrm{a}}$ & $\begin{array}{l}\text { Whether or not there is any irrigational work in the commune } \\
\text { in which the household lived }\end{array}$ & + \\
\hline Post office ${ }^{\mathrm{a}}$ & $\begin{array}{l}\text { Whether or not there is any post office in the commune in } \\
\text { which the household lived }\end{array}$ & + \\
\hline $\begin{array}{l}\text { Non-farm } \\
\text { opportunities }\end{array}$ & $\begin{array}{l}\text { Whether or not there is any production/services unit or trade } \\
\text { village located within such a distance that the people in the } \\
\text { commune can go there to work and then go home every day }\end{array}$ & + \\
\hline Population density & Number of people per one square kilometer & $+1-$ \\
\hline
\end{tabular}

Notes: ${ }^{\mathrm{a}}$ Indicates dummy variables $\left(1=\mathrm{yes} ; 0=\right.$ otherwise). ${ }^{\mathrm{b}}$ This ratio is calculated by the number of female members aged under 15 and over 59, and male members aged under 15 and over 65, divided by the number of female members aged 15-59 and male members aged 15-64. 
We ran two models. Model 1 used all household variables but not commune variables, while Model 2 included both commune and household variables. The two models are expressed as follows:

Model 1:

Log of per capita household income $=\beta_{1}$ demographics $+\beta_{2}$ education + $\beta_{3}$ land $+\beta_{4}$ fixed assets $+\beta_{5}$ credit $+\beta_{6}$ nonfarm employment $+\varepsilon$

Model 2:

Log of per capita household income $=\beta_{1}$ demographics $+\beta_{2}$ education + $\beta_{3}$ land $+\beta_{4}$ fixed assets $+\beta_{5}$ credit $+\beta_{6}$ nonfarm employment + $\beta_{7}$ commune characteristics $+\varepsilon$

We addressed the heteroscedasticity by transforming income per capita and value of fixed assets into their natural logarithms. In addition, the option "pweight" in STATA was used to account for sampling weights, which also produces robust standard errors in both models. In order to identify possible indications of multicollinearity, a correlation matrix analysis and an analysis of the variance inflation factor (VIF) were conducted. The results confirm that both models do not suffer from multicollinearity problems.

\section{Results and Discussion}

\subsection{Background on Household Characteristics and Income}

Table 2 shows that there are considerable differences in the mean values of most household characteristics between the two groups. The poor had a larger household size and much higher dependency ratio than the non-poor. The differences in the age and education of household heads between the two groups were also statistically significant. The heads of poor households were approximately three years younger than those of non-poor households. The heads of poor households attained a lower rate of school completion (at all levels) than those of non-poor households. Unsurprisingly, the participation rates in both wage employment 
and non-farm self-employment were found to be lower for the poor than the non-poor. However, the rate of credit participation was not different between the two groups.

Table 2: Descriptive Statistics of Household and Commune Characteristics, by Income Group

\begin{tabular}{|c|c|c|c|c|c|c|c|}
\hline \multirow{2}{*}{ Explanatory variables } & \multicolumn{2}{|c|}{ All housebolds } & \multicolumn{2}{|c|}{$\begin{array}{l}\text { Non-poor } \\
\text { households }\end{array}$} & \multicolumn{2}{|c|}{ Poor households } & \multirow{2}{*}{\begin{tabular}{|c} 
t-value \\
or \\
$\begin{array}{c}\text { Pearson } \\
\text { chi2 }\end{array}$ \\
\end{tabular}} \\
\hline & Mean & SD & Mean & SD & Mean & SD & \\
\hline \multicolumn{8}{|l|}{ Household characteristics } \\
\hline Household size & 6.01 & $(2.32)$ & 5.22 & $(1.80)$ & 6.40 & $(2.50)$ & $* * *$ \\
\hline Dependency ratio & 0.83 & $(0.69)$ & 0.58 & $(0.60)$ & 0.97 & $(0.70)$ & $* * *$ \\
\hline Age of household head & 41.46 & $(12.82)$ & 43.23 & $(12.06)$ & 40.44 & $(13.13)$ & $* * *$ \\
\hline $\begin{array}{l}\text { Gender of household } \\
\text { head }^{\mathrm{a}}\end{array}$ & 0.92 & $(0.26)$ & 0.92 & $(0.27)$ & 0.93 & $(0.26)$ & \\
\hline $\mathrm{Credit}^{\mathrm{a}}$ & 0.40 & $(0.49)$ & 0.41 & $(0.49)$ & 0.39 & $(0.49)$ & \\
\hline Wage employment ${ }^{\mathrm{a}}$ & 0.32 & $(0.47)$ & 0.45 & $(0.50)$ & 0.25 & $(0.43)$ & ${ }^{* * *}$ \\
\hline $\begin{array}{l}\text { Non-farm self- } \\
\text { employment }\end{array}$ & 0.11 & $(0.32)$ & 0.14 & $(0.34)$ & 0.10 & $(0.30)$ & * \\
\hline \multicolumn{8}{|l|}{ Education } \\
\hline Primary ${ }^{a}$ & 0.23 & $(0.42)$ & 0.25 & $(0.43)$ & 0.21 & $(0.41)$ & $* * *$ \\
\hline Lower secondary ${ }^{\mathrm{a}}$ & 0.18 & $(0.38)$ & 0.25 & $(0.43)$ & 0.14 & $(0.34)$ & $* * *$ \\
\hline $\begin{array}{l}\text { Upper secondary and } \\
\text { higher }^{\mathrm{a}}\end{array}$ & 0.05 & $(0.21)$ & 0.09 & $(0.29)$ & 0.02 & $(0.14)$ & *** \\
\hline \multicolumn{8}{|l|}{ Assets/wealth } \\
\hline Annual crop land & 1,851 & $(1,736)$ & 2,432 & $(2,197)$ & 1,574 & $(1,312)$ & $* * *$ \\
\hline Perennial crop land & 95.7 & $(506)$ & 178 & $(755)$ & 48.6 & $(267)$ & $* * *$ \\
\hline Forestry land & 1,517 & $(8,557)$ & 1,262 & $(5,032)$ & 1,661 & $(1,003)$ & $* * *$ \\
\hline $\begin{array}{l}\text { Water surface for } \\
\text { aquaculture }\end{array}$ & 16.17 & (190) & 24.74 & (130) & 11.30 & (219) & \\
\hline Fixed assets & 23.60 & $(28.82)$ & 35.00 & $(40.40)$ & 16.72 & $(15.05)$ & $* * *$ \\
\hline $\begin{array}{l}\text { Monthly income per } \\
\text { capita }^{b}\end{array}$ & 390 & (336) & 712 & $(432)$ & 238 & (84) & $* * *$ \\
\hline \multicolumn{8}{|l|}{ Commune characteristics } \\
\hline Paved road ${ }^{\mathrm{a}}$ & 0.22 & $(0.42)$ & 0.22 & $(0.42)$ & 0.23 & $(0.42)$ & * \\
\hline Means of transportation ${ }^{a}$ & 0.33 & $(0.47)$ & 0.40 & $(0.49)$ & 0.29 & $(0.46)$ & $* * *$ \\
\hline Irrigational work ${ }^{\mathrm{a}}$ & 0.77 & $(0.42)$ & 0.78 & $(0.41)$ & 0.77 & $(0.42)$ & \\
\hline Post office ${ }^{a}$ & 0.93 & $(0.25)$ & 0.96 & $(0.19)$ & 0.91 & $(0.28)$ & $* * *$ \\
\hline Electricity $^{a}$ & 0.95 & $(0.21)$ & 0.93 & $(0.25)$ & 0.98 & $(0.13)$ & \\
\hline Local marketa & 0.22 & $(0.41)$ & 0.23 & $(0.42)$ & $(0.22)$ & $(0.41)$ & \\
\hline $\begin{array}{l}\text { Non-farm job } \\
\text { opportunities }\end{array}$ & 0.23 & $(0.42)$ & 0.30 & $(0.46)$ & 0.19 & $(0.39)$ & ${ }^{* * *}$ \\
\hline Population density & 156 & $(379)$ & 196 & $(425)$ & 133 & $(349)$ & * \\
\hline
\end{tabular}

Notes: Estimates are adjusted for sampling weights. SD: standard deviations. ${ }^{*},{ }^{* *},{ }^{* * *}$ Mean statistically significant at $10 \%, 5 \%$ and $1 \%$, respectively. ${ }^{\mathrm{a}}$ Indicates dummy variables. ${ }^{\mathrm{b}}$ Measured in 1,000 VND. 1 USD was equal to about 19,000 VND in 2010 
Table 2 shows that the poor earned a very low level of per capita income, equivalent to one-third of that earned by the non-poor. The differences in all types of land and the total value of fixed assets between the two groups are found to be highly statistically significant. The area of annual crop land per capita held by non-poor households was quite bigger than that owned by poor households. In addition, non-poor households had much more perennial crop land than poor households. However, the non-poor owned less forestry land than the poor. This can be explained by the fact that there are several programs and policies that have provided forestry land for the ethnic minority poor in this region (Cuong, 2012). The non-poor also had a total value of fixed assets that nearly doubled that of the poor. Remarkable differences in some household characteristics and assets between the two groups were expected to be closely linked with variations in household income.

Table 3: Household Income Share by Source

\begin{tabular}{l|c|c|c|c}
\hline Income sources & $\begin{array}{c}\text { Kinh ethnic } \\
\text { majority }\end{array}$ & $\begin{array}{c}\text { Ethnic } \\
\text { minorities }\end{array}$ & $\begin{array}{c}\text { Non-poor } \\
\text { ethnic } \\
\text { minorities }\end{array}$ & $\begin{array}{c}\text { Poor ethnic } \\
\text { minorities }\end{array}$ \\
\hline Wage employment & 0,42 & 0,11 & 0,17 & 0,07 \\
\hline Non-farm self-employment & 0,19 & 0,02 & 0,03 & 0,01 \\
\hline Crop & 0,15 & 0,62 & 0,45 & 0,72 \\
\hline Livestock & 0,04 & 0,09 & 0,13 & 0,07 \\
\hline Forestry & 0,01 & 0,06 & 0,10 & 0,04 \\
\hline Aquaculture & 0,02 & 0,01 & 0,02 & 0,01 \\
\hline Other & 0,17 & 0,09 & 0,12 & 0,08 \\
\hline
\end{tabular}

Source: Author's own calculation from the 2010 NMBS and Vietnam Household Living Standard Survey 2010 (VHLSS 2010).

Table 3 shows that agriculture activities contributed the largest share of total household income for ethnic minorities in the North-West Mountains. Combined together, the income from crop, livestock, forestry and aquaculture accounted for nearly 80 percent of total income. However, the income from nonfarm activities (wage employment and self-employment) made up only about 13 percent of total income, while the remaining share came from other sources. 
By contrast, the income from non-farm sources contributed about 60 percent of total income for Kinh ethnic majority households. This implies that agriculture continues to play an important role in the livelihood of the ethnic minorities in the study region. A closer look at the income structure of income groups revealed that the crop income share of the poor is much larger than that of the nonpoor. Nevertheless, the poor received less income from forestry and livestock than the non-poor. The poor also earned much less income from both wage employment and non-farm self-employment than the non-poor. In addition, the poor received less income from other sources than the non-poor. The data suggest that differences in income sources between the two groups might explain the differences in income per capita between them.

\subsection{Determinants of Household Income}

Table 3 reports the results from Model 1 with household variables and Model 2 with both commune and household variables. As compared to Model 1, Model 2 has a higher R-squared value with more statistically significant variables. Model 2 explains roughly 50 percent of the variation in household income. In addition, many coefficients are highly statistically significant $(\mathrm{p}<0.05)$ with their signs as expected. As shown in Model 2, the coefficient of wage employment indicates that, holding all other variables constant, households that took up wage employment had, on average, an income per capita level approximately 30 percent higher than those without non-farm employment. The corresponding figures for households with non-farm self-employment were about 14 percent. This suggests that households can significantly improve their income by participating in any type of non-farm employment. In general, this finding is also in accordance with that of Pham, Bui and Dao (2010), Van de Walle and Cratty (2004) and Tuyen et al. (2014). 
Table 4: Determinants of Household Income

\begin{tabular}{|c|c|c|c|c|}
\hline \multirow{2}{*}{ Explanatory variables } & \multicolumn{2}{|c|}{ Model 1} & \multicolumn{2}{|c|}{ Model 2} \\
\hline & Coefficient & SE & Coefficient & SE \\
\hline \multicolumn{5}{|l|}{ Household characteristics/assets } \\
\hline Household size & $-0.0891^{* * *}$ & $(0.008)$ & $-0.0908^{* * *}$ & $(0.009)$ \\
\hline Dependency ratio & $-0.0681^{* * *}$ & $(0.023)$ & $-0.0599^{* *}$ & $(0.025)$ \\
\hline Age & $0.0251^{* * *}$ & $(0.007)$ & $0.0266^{* * *}$ & $(0.008)$ \\
\hline Age squared & $-0.0002^{* * *}$ & $(0.000)$ & $-0.0002^{* * *}$ & $(0.000)$ \\
\hline Gender & -0.0864 & $(0.057)$ & -0.0964 & $(0.068)$ \\
\hline Primary education & $0.0756^{* *}$ & $(0.037)$ & $0.0710^{*}$ & $(0.040)$ \\
\hline Lower secondary education & $0.2047^{* * *}$ & $(0.045)$ & $0.1974^{* * *}$ & $(0.046)$ \\
\hline Upper secondary education and higher & $0.5208^{* * *}$ & $(0.081)$ & $0.5333^{* * *}$ & $(0.084)$ \\
\hline Annual crop land & $0.0123^{* * *}$ & $(0.001)$ & $0.0119^{* * *}$ & $(0.001)$ \\
\hline Perennial crop land & $0.0111^{* * *}$ & $(0.004)$ & $0.0095^{* *}$ & $(0.004)$ \\
\hline Forestry land & -0.0001 & $(0.000)$ & -0.0001 & $(0.000)$ \\
\hline Water surface for aquaculture & 0.0143 & $(0134)$ & 0.0127 & $(0.011)$ \\
\hline Fixed assets & $0.1614^{* * *}$ & $(0.015)$ & $0.1732^{* * *}$ & $(0.016)$ \\
\hline Credit & 0.0003 & $(0.000)$ & 0.0001 & $(0.000)$ \\
\hline Wage employment & $0.2758^{* * *}$ & $(0.034)$ & $0.2913^{* * *}$ & $(0.036)$ \\
\hline Non-farm self-employment & 0.0666 & $(0.049)$ & $0.1428^{* * *}$ & $(0.052)$ \\
\hline \multicolumn{5}{|l|}{ Commune characteristics } \\
\hline Paved road & & & -0.0098 & $(0.034)$ \\
\hline Local market & & & -0.0103 & $(0.035)$ \\
\hline Means of transportation & & & $0.1724^{* * *}$ & $(0.035)$ \\
\hline Post office & & & $0.2430^{* *}$ & $(0.106)$ \\
\hline Electricity & & & 0.1999 & $(0.132)$ \\
\hline Irrigational work & & & 0.0386 & $(0.041)$ \\
\hline Non-farm job opportunities & & & $0.0940^{* *}$ & $(0.040)$ \\
\hline Population density & & & $-0.0001^{*}$ & $(0.000)$ \\
\hline Constant & $3.8063^{* * *}$ & $(0.206)$ & $3.1565^{* * *}$ & $(0.258)$ \\
\hline Observations & 1,594 & & 1,374 & \\
\hline R-squared & 0.450 & & 0.484 & \\
\hline
\end{tabular}

Notes: Estimates are adjusted for sampling weights; robust standard errors (SE) in parentheses; ${ }^{* * *} \mathrm{p}<0.01,{ }^{* *} \mathrm{p}<0.05$, ${ }^{*} \mathrm{p}<0.1$.

Both household size and dependency ratio are negatively related to income per capita. The finding is consistent with Jansen et al. (2006) and Tuyen et al. (2014) who found that having more dependent members and more family members in general, seems to reduce per capita income. Holding all other variables constant, 
an additional family member corresponds with a decrease in income per capita of about 9 percent in both models. The positive sign of the age of household head and the negative sign of its squared term suggest that the age of household head has a diminishing impact on household income. Not as expected, the gender of household head does not affect household income. All levels of education have an increasing effect on household income per capita and this effect significantly increases with the levels of education. The income per capita is 7 percent, 20 percent and 53 percent higher for a household with a head holding a primary school diploma, a lower secondary school diploma and an upper secondary school diploma or higher, respectively. Similar findings were also found in previous studies in peri-urban Vietnam (Tuyen et al., 2014) and rural Vietnam (Nguyen, Kant and MacLaren, 2004).

Regarding the role of assets in household income, the study found that not all types of land are associated with household income. While both annual and perennial crop land have a positive effect on household income, this effect was not found for the case of forestry land. An increase of $100 \mathrm{~m} 2$ of annual crop land per capita and that of perennial crop land per capita result in an increase in per capita income of 1.2 percent and 0.9 percent, respectively. This finding is consistent with previous studies (Tuyen et al., 2014; Van de Walle and Cratty, 2004) which found a positive relationship between farmland holding and household income in Vietnam's rural and peri-urban areas. The current study found evidence for a significantly positive association between fixed assets and household income. The elasticity of income per capita to higher values of fixed assets is around 0.17 in both models. Nevertheless, we found no statistical relationship between credit and household income. Overall, these findings are in line with Nghiem, Coelli and Rao (2012) who found that land and assets have an increasing effect on household welfare in Vietnam.

This study found that some commune variables have a significantly positive effect on household income. Households with equal assets and other characteristics have, on average, an income per capita level that is about 17 percent higher if 
they live in communes with the presence of means of transportation. Similarly, living in a commune with access to a post office and non-farm job opportunities increases household income by 24 percent and 9.4 percent, respectively. The findings suggest that household income is considerably affected by some communal factors.

\section{Conclusion and Policy Implications}

The objective of this paper is to examine the socio-economic determinants of household income among ethnic minorities in the North-West Mountains, Vietnam. Using a unique dataset from a household survey in the study area, this study offers the first evidence of factors determining household income of ethnic minorities in the poorest region of Vietnam. We found that some of both household and commune related factors have significant effects on household income. This suggests that policies for poverty reduction should aim at both household and community levels.

The result of this study shows a strong positive association between non-farm employment and household income. Both participation in wage employment and self-employment in non-farm activities have rising effects on income per capita. A useful policy implication here is that ethnic minorities can improve their income by intensively taking up non-farm activities. Nevertheless, their ability to access non-farm activities was found to be dependent on several factors at both household and commune levels. These include education, fixed assets, the presence of local enterprises and trade villages, and improved local infrastructure (Tuyen, 2014c). The accumulation, value, usefulness of and access to these factors can be greatly affected by institutions and state policies. As a result, policy intervention in these factors can enable households to participate actively in nonfarm activities, which in turn can help them improve income and escape poverty.

The regression analysis indicates that some other variables have a positive relationship with household income. Having more annual and perennial crop 
land increases household income. However, land distribution policy should not be regarded as a main approach to rural poverty eradication since land is fixed in supply. Instead, improving the access of households to non-farm activities should be considered a very important policy for poverty alleviation in the study area. This is because non-farm employment was found to be a powerful engine for poverty reduction in the North-West region (Cuong, 2012; Tuyen et al., 2015). Education and fixed assets have a positive effect on income per capita. Therefore, a possible implication here is that governmental support for households' access to formal credit can help them have more financial resources and accumulate more productive assets; these, in turn, allow them to earn higher income. Encouraging and increasing investment in children's education might help the next generation take up lucrative non-farm jobs and improve living standards in the study area.

Finally, we found evidence that some commune characteristics such as the presence of means of transportation, post offices and non-farm job opportunities have a positive impact on household income. It is possible to suggest that promoting the availability of means of transportation and promoting rural non-farm activities, combined with building up post offices, are expected to help ethnic minorities gain access to non-farm employment and improve their household income.

\section{Acknowledgments}

The author thanks Vietnam National University, Hanoi and VNU University of Economics and Business for funding this research. I also thank my colleagues for their helpful comments on earlier versions of this paper. 


\section{Literature}

Ackah, Charles, 2013, "Nonfarm Employment and Incomes in Rural Ghana", Journal of International Development, 25(3), pp. 325-339. http://dx.doi. org/10.1002/jid.1846

Barnard, Helen and Claire Turner, 2011, "Poverty and Ethnicity: A Review of Evidence", Policy and Research, York: Joseph Rowntree Foundation.

Baulch, Bob, Truong Thi Kim Chuyen, Dominique Haughton and Jonathan Haughton, 2007, "Ethnic Minority Development in Vietnam", The Journal of Development Studies, 43(7), pp. 1151-1176. http://dx.doi. org/10.1080/02673030701526278

Baulch, Bob, Hoa Thi Minh Nguyen, Phuong Thi Thu Nguyen and Hung Thai Pham, 2011, "Ethnic Minority Poverty in Vietnam" in Thang Nguyen, ed., Poverty Vulnerability and Social Protection in Vietnam: Selected Issues, pp. 101165, Hanoi: Vietnam Academy of Social Sciences.

Benin, Samuel and Josee Randriamamonj, 2008, Estimating Household Income to Monitor and Evaluate Public Investment Programs in Sub-Saharan Africa, Washington, DC: International Food Policy Research Institute.

Bhalla, Ajit and Dan Luo, 2012, Poverty and Exclusion of Minorities in China and India, Hampshire: Palgrave Macmillan. http://dx.doi. org/10.1057/9781137283535

Carletto, Gero, Katia Covarrubias, Davis Benjamin, Marika Krausova, Kostas Stamoulis, Paul Winters and Alberto Zezza, 2007, "Rural Income Generating Activities in Developing Countries: Re-assessing the Evidence", Electronic Journal of Agricultural and Development Economics, 4(1), pp. 146-193.

Cuong, Nguyen Viet, 2008, "Is a Governmental Micro-credit Program for the Poor Really Pro-poor? Evidence from Vietnam", The Developing Economies, 46(2), pp. 151-187. http://dx.doi.org/10.1111/j.1746-1049.2008.00061.x 
Cuong, Nguyen Viet, 2012, "Ethnic Minorities in Northern Mountains of Vietnam: Poverty, Income and Assets", MPRA Working Paper, No. 40769, Munich: Munich University Library.

Estudillo, Jonna, Yasuyuki Sawada and Keijiro Otsuka, 2008, "Poverty and Income Dynamics in Philippine Villages, 1985-2004", Review of Development Economics, 12(4), pp. 877-890. http://dx.doi.org/10.1111/j.1467-9361.2008.00458.x

Gauri, Varun, 2001, "Are Incentives Everything? Payment Mechanisms for Health Care Providers in Developing Countries”, WPS 2624, Washington, DC: World Bank. http://dx.doi.org/10.1596/1813-9450-2624

Gustafsson, Björn Anders and Ding Sai, 2008, "Temporary and Persistent Poverty among Ethnic Minorities and the Majority in Rural China”, IZA Discussion Paper, No. 3791, Bonn: The Institute for the Study of Labor (IZA).

Hassan, Rashid and Suresh Chandra Babu, 1991, "Measurement and Determinants of Rural Poverty: Household Consumption Patterns and Food Poverty in Rural Sudan”, Food Policy, 16(6), pp. 451-460. http://dx.doi. org/10.1016/0306-9192(91)90045-L

Jansen, Hans, John Pender, Amy Damon, Wilem Wielemaker and Rob Schipper, 2006, "Policies for Sustainable Development in the Hillside Areas of Honduras: A Quantitative Livelihoods Approach”, Agricultural Economics, 34(2), pp.141-153. http://dx.doi.org/10.1111/j.1574-0864.2006.00114.x

Jolliffe, Dean, 1997, "Whose Education Matters in the Determination of Household Income: Evidence from a Developing Country", FCND Discussion Paper, No. 39, Washington, DC: International Food Policy Research Institute.

Kassali, Rabirou, Adeolu Babatunde Ayanwale, Ezekiel Olukayode Idowu and Stella Bola Williams, 2012, "Effect of Rural Transportation System on Agricultural Productivity in Oyo State, Nigeria", Journal of Agriculture and Rural Development in the Tropics and Subtropics, 113(1), pp.13-19.

Kenway, Peter and Guy Palmer, 2007, Poverty among Ethnic Groups: How and Why Does It Differ?, York: New Policy Institute. 
Khandker, Shahidur, Douglas Barnes, Hussain Samad and Nguyen Huu Minh, 2009, "Welfare Impacts of Rural Electrification: Evidence from Vietnam", World Bank Policy Research Working Paper, No. 5057, Washington, DC: World Bank.

Lanjouw, Peter and Martin Ravallion, 1995, "Poverty and Household Size", Economic Journal, 105(4), pp. 1415-1434. http://dx.doi.org/10.2307/2235108

Micevska, Maja and Dil Bahadur Rahut, 2008, "Rural Nonfarm Employment and Incomes in the Himalayas", Economic Development and Cultural Change, 57(1), pp. 163-193. http://dx.doi.org/10.1086/590460

Minot, Nicholas, 2000, "Generating Disaggregated Poverty Maps: An Application to Vietnam", World Development, 28(2), pp. 319-331. http://dx.doi. org/10.1016/S0305-750X(99)00126-6

Nghiem, Son, Tim Coelli and Prasada Rao, 2012, "Assessing the Welfare Effects of Microfinance in Vietnam: Empirical Results from a Quasi-experimental Survey", Journal of Development Studies, 48(5), pp. 619-632. http://dx.doi.org/10 $.1080 / 00220388.2011 .638051$

Nguyen, Van Ha, Shashi Kant and Virginia MacLaren, 2004, "The Contribution of Social Capital to Household Welfare in a Paper-Recycling Craft Village in Vietnam", The Journal of Environment and Development, 13(4), pp. 371-399. http://dx.doi.org/10.1177/1070496504268345

Otsuka, Keijiro and Takashi Yamano, 2006, "Introduction to the Special Issue on the Role of Nonfarm Income in Reduction: Evidence from Asia and East Africa", Agricultural Economics, 35(3), pp. 393-397. http://dx.doi.org/10.1111/ j.1574-0862.2006.00185.x

Pham, Hung Thai, Anh Tuan Bui and Le Thanh Dao, 2010, "Is Nonfarm Diversification a Way Out of Poverty for Rural Households? Evidence from Vietnam in 1993-2006", Poverty and Economic Poverty PMMA Working Paper 2010-17, http://ssrn.com/abstract=1715603 (accessed 15 December 2014). 
Rigg, Jonathan, 2006, “Land, Farming, Livelihoods, and Poverty: Rethinking the Links in the Rural South", World Development, 34(1), pp. 180-202. http:// dx.doi.org/10.1016/j.worlddev.2005.07.015

Ruben, Ruerd and Marrit Van den Berg, 2001, "Nonfarm Employment and Poverty Alleviation of Rural Farm Households in Honduras", World Development, 29(3), pp. 549-560. http://dx.doi.org/10.1016/S0305-750X(00)00107-8

Schultz, Theodore, 1961, "Investment in Human Capital", American Economic Review, 51(1), pp. 1-17.

Simler, Kenneth, Sanjukta Mukherjee, Gabriel Dava and Gaurav Datt, 2004, "Rebuilding after War: Micro-level Determinants of Poverty Reduction in Mozambique", Research Report 132, Washington, DC: International Food Policy Research Institute.

Thorat, Sukhadeo and Katherine Newman, 2007, "Caste and Economic Discrimination: Causes, Consequences and Remedies", Economic and Political Weekly, 42(41), pp. 4121-4124.

Tijani, NiYi Moshood, Abiodun Elijah Obayelu, Adeyinka Sobowale and Akinade Shadrach Olatunji, 2014, "Welfare Analysis of Smallholder Farmers by Irrigation Systems and Factors Affecting Their Production Outputs in Nigeria", Sustainability of Water Quality and Ecology, 3-4(0), pp. 90-100. http://dx.doi. org/10.1016/j.swaqe.2014.12.002

Tuyen, Tran Quang, 2014a, "The Impact of Farmland Loss on Income Distribution of Households in Hanoi's Peri-urban Areas, Vietnam", Hitotsubashi Journal of Economics, 55(2), pp. 189-206.

Tuyen, Tran Quang, 2014b, "A Review on the Link between Nonfarm Employment, Land and Rural Livelihoods in Developing Countries and Vietnam", Ekonomski horizonti, 16(2), pp. 113-123.

Tuyen, Tran Quang, 2014c, "Determinants of Nonfarm Participation among Ethnic Minorities in the Northwest Mountains, Vietnam", MPRA Working Paper, No. 59185, Munich: Munich University Library. 
Tuyen, Tran Quang, Steven Lim, Michael Cameron and Huong Van Vu, 2014, "Farmland Loss and Livelihood Outcomes: A Microeconometric Analysis of Household Surveys in Vietnam", Journal of the Asia Pacific Economy, 19(3), pp. 423-444. http://dx.doi.org/10.1080/13547860.2014.908539

Tuyen, Tran Quang, Son Hong Nguyen, Huong Van Vu and Viet Nguyen Quoc, 2015, "A Note on Poverty among Ethnic Minorities in the North-West Region of Vietnam", Post-Communist Economies, 27(2), pp. 268-281. http://dx.doi.org/10.1 080/14631377.2015.1026716

Van de Walle, Dominique and Dorothyjean Cratty, 2004, "Is the Emerging Non-farm Market Economy the Route Out of Poverty in Vietnam?", Economics of Transition, 12(2), pp. 237-274. http://dx.doi.org/10.1111/j.09670750.2004.00178.x

Van de Walle, Dominique and Dileni Gunewardena, 2001, "Sources of Ethnic Inequality in Viet Nam", Journal of Development Economics, 65(1), pp. 177-207. http://dx.doi.org/10.1016/S0304-3878(01)00133-X

Weiss, Randall, 1970, "The Effect of Education on the Earnings of Blacks and Whites", The Review of Economics and Statistics, 52(2), pp. 150-159. http://dx.doi. org/10.2307/1926115

Welch, John, 1970, "Education in Production", Journal of Political Economy, 78(1), pp. 35-59. http://dx.doi.org/10.1086/259599

World Bank, 2012, 2012 Vietnam Poverty Assessment - Well Begun, Not Yet Done: Vietnam's Remarkable Progress on Poverty Reduction and the Emerging Challenges, Washington, DC: World Bank.

Yúnez-Naude, Antonio and J. Edward Taylor, 2001, "The Determinants of Nonfarm Activities and Incomes of Rural Households in Mexico, with Emphasis on Education", World Development, 29(3), pp. 561-572. http://dx.doi. org/10.1016/S0305-750X(00)00108-X 